\title{
Commentary Superantigen antagonist peptides
}

Martin Llewelyn and Jonathan Cohen

Department of Infectious Diseases, Imperial College School of Medicine, Hammersmith Hospital, London, UK

Correspondence: Jon Cohen, Department of Infectious Diseases and Microbiology, Division of Investigative Science, Imperial College of Medicine, The Hammersmith Hospital, Du Cane Road, London W12 0NN, UK. Tel: +44 (0) 208383 3243; fax: +44 (0) 208383 3394; email: j.cohen@ic.ac.uk

Received: 8 January 2001

Accepted: 19 January 2001

Published: 26 February 2001
Critical Care 2001, 5:53-55

(C) 2001 BioMed Central Ltd

(Print ISSN 1364-8535; Online ISSN 1466-609X)

\begin{abstract}
The production of superantigenic exotoxins by Gram positive bacteria underlies the pathology of toxic shock syndrome. Future treatment strategies for superantigen-mediated diseases are likely to be directed at blocking the three-way interaction between superantigen, $\mathrm{T}$ cell receptor and major histocompatibility class II molecule, which inititates an excessive and disordered inflammatory response. In this article, we review the first published data to address one such strategy in the context of other recognised and experimental treatments.
\end{abstract}

Keywords: exotoxins, immunology, septic, shock, superantigen, treatment

Gram-positive infections account for up to $50 \%$ of cases of severe sepsis in the modern intensive care unit. The complex processes by which Gram-positive organisms cause sepsis are poorly understood by comparison with Gram-negative sepsis. Much interest is currently focused on the role of certain protein exotoxins synthesized by Staphylococcus aureus and Streptococcus pyogenes, which share the immunological property of being superantigens. Superantigens are characterized by the ability to bypass normal major histocompatibility complex (MHC)restricted, intracellular, antigen processing and presentation. Through direct binding to the MHC class II molecule and the $T$ cell receptor, at sites away from those involved in conventional antigen binding, superantigens activate up to $50 \%$ of the whole T cell repertoire rather than the $1 \%$ fraction stimulated by conventional antigens. The precise biological advantage of superantigen production to these organisms is uncertain. Such toxins are, however, believed to have a role in causation of two classic superantigenmediated diseases, staphylococcal and streptococcal toxic shock syndromes, that kill 5000 Americans per annum. They may also contribute to the pathogenesis of other forms of Gram-positive shock.
In addition to intensive care support and antimicrobial therapy, various adjunctive treatments for toxic shock syndrome have been evaluated both in vitro and in clinical trials (Table 1). Nevertheless, the treatment of toxic shock syndrome, like that of conventional forms of sepsis, remains suboptimal and the disease is still associated with mortality in the region of $50 \%$ and associated with considerable morbidity.

Arad et al reported a novel approach to treatment of superantigen-mediated disease [1]. They identified a dodecapeptide that is highly conserved among different bacterial superantigens and lies in a region of the superantigen molecule away from sites involved with either MHC class II or T cell receptor interaction. Several modified forms of this peptide acted as antagonists to a range of bacterial superantigens against which they were tested in vitro. One dodecapeptide, which was a particularly effective antagonist, was administered to mice challenged with bolus doses of bacterial superantigen. The peptide was protective both before and after superantigen challenge. Arad et al speculate that the mechanism of inhibition may involve co-stimulatory pathways of $\mathrm{T}$ cell

$\mathrm{MHC}=$ major histocompatibilty complex. 
Table 1

Specific approaches to treatment of toxic shock syndromes

\begin{tabular}{ll}
\hline Strategy & Experimental data \\
\hline Clindamycin & $\begin{array}{l}\text { Toxin production is switched off at sub-bacteriocidal concentrations of antibiotic. } \\
\text { Clindamycin use is associated with reduced mortality compared with historical controls }\end{array}$ \\
Intravenous immunoglobulin & $\begin{array}{l}\text { Immunoglobulin neutralizes streptococcal pyrogenic exotoxins in vitro. IgA and lgM } \\
\text { supplemented preparations may be superior to pure lgG preparations. Adjunctive therapy } \\
\text { with intravenous immunoglobulin is associated with improved survival compared with } \\
\text { historical controls }\end{array}$ \\
Toxoids of pyrogenic exotoxins & Non-superantigenic mutants of SPEA and SPEC protect rabbits from a toxin challenge
\end{tabular}

SPEA, Streptococcal pyrogenic exotoxin A; SPEC, streptococcal pyrogenic exotoxin C.

activation. Interestingly, protection against subsequent challenges, at 3-weekly intervals, improved with each challenge. This improved protection correlated with antibody production against the whole challenge superantigen, while antibody against the dodecapeptide was not detected. This finding is in keeping with the previously observed correlation between lack of antibody against streptococcal pyrogenic exotoxin A and development of invasive S. pyogenes infection [2]. One consequence of the cytokine storm induced by superantigens may be to disrupt the development of antibody-mediated immunity. By switching off superantigenicity, the dodecapeptide may be allowing normal antibody production to occur.

Although the prospect of drugs to switch off superantigenicity is exciting, there have been many false dawns in the field of sepsis research. Animal studies of superantigen-mediated human disease have well recognized limitations. All laboratory animals are intrinsically resistant to the effects of bacterial superantigens. The mouse model, while being one of the best established systems for studying toxic shock, requires far higher doses of superantigen than are needed to induce shock in humans, and prior 'sensitization' of the animal with the hepatotoxin D-galactosamine. We have recently demonstrated, in a mouse model of invasive streptococcal infection, that other properties of these toxins may be more important than their superantigenicity and, paradoxically, such effects may in fact be advantageous to the host [3]. Furthermore, administration of bolus doses of superantigen probably does not reflect the pattern of toxin production in clinical cases.

Certain findings of the report by Arad et al are at odds with our current understanding of bacterial superantigens. The study found that animals protected from one superantigen in an initial challenge were cross-protected against different superantigens in subsequent challenges. This effect was observed for toxins as dissimilar as staphylococcal exotoxin B and toxic shock syndrome toxin 1 , which have only $6 \%$ sequence homology. This is hard to understand in terms of neutralizing antibody since no cross-reactivity between toxic shock syndrome toxin 1 and other superantigens has been demonstrated in serological or neutralization assays.

The paper by Arad et al is the first published report of superantigen antagonist peptides. Encouragingly, at least one other group is making progress in the same area, and have demonstrated a protective effect not only against bolus doses of superantigen, but also in a model of cochallenge with endotoxin [4]. Further studies to address the mode of action of these peptides, particularly in superantigen-sensitive animal models (Sriskandan et al, manuscript submitted), are necessary before speculation about clinical trials is warranted.

We welcome letters on any aspect or issue covered in this journal. Letters should be under 400 words and include no more than 5 references, one of which should be the article it relates to. Email your letters to editorial@ccforum.com

\section{References}

1. Arad G, Levy R, Hillman D, Kaempfer R: Superantigen antagonist protects against lethal shock and defines a new domain for T-cell activation. Nat Med 2000, 6:414-421.

2. Eriksson BK, Andersson J, Holm SE, Norgren M: Invasive group A streptococcal infections: $\mathrm{T} 1 \mathrm{M} 1$ isolates expressing pyrogenic exotoxins $A$ and $B$ in combination with selective lack of toxin-neutralizing antibodies are associated with increased risk of streptococcal toxic shock syndrome. J Infect Dis 1999, 180:410-418.

3. Sriskandan S, Unnikrishnan M, Krausz T, Cohen J: Molecular analysis of the role of streptococcal pyrogenic exotoxin A (SPEA) in invasive soft tissue infection resulting from Streptococcus pyogenes. Mol Microbiol 1999, 33:778-790.

4. Visvanathan K, Charles A, Bannan J, Pugach P, Kashfi K, Zabriskie JB: Inhibition of bacterial superantigens by peptides and antibodies. Infect Immun 2001, 69:875-884.

5. Sriskandan S, McKee A, Hall L, Cohen J: Comparative effects of clindamycin and ampicillin on superantigenic activity of streptococcus pyogenes. J Antimicrob Chemother 1997, 40:275-277.

6. Zimbelman J, Palmer A, Todd J: Improved outcome of clindamycin compared with beta-lactam antibiotic treatment for invasive streptococcus pyogenes infection. Pediatr Infect Dis J 1999, 18:1096-1100. 
7. Norrby-Teglund A, Kaul R, Low DE, McGeer A, Newton DW, Andersson J, Andersson U, Kotb M: Plasma from patients with severe invasive group A streptococcal infections treated with normal polyspecific IgG inhibits streptococcal superantigeninduced $\mathrm{T}$ cell proliferation and cytokine production. $J$ Immunol 1996, 156:3057-3064.

8. Norrby-Teglund A, Ihendyane N, Kansal R, Basma H, Kotb M, Andersson J, Hammarstrom L: Relative neutralizing activity in polyspecific $\lg M$, IgA, and IgG preparations against group $A$ streptococcal superantigens. Clin Infect Dis 2000, 31:11751182.

9. Kaul R, McGeer A, Norrby-Teglund A, Kotb M, Schwartz B, O'Rourke K, Talbot J, Low DE: Intravenous immunoglobulin therapy for streptococcal toxic shock syndrome - a comparative observational study. The Canadian Streptococcal Study Group. Clin Infect Dis 1999, 28:800-807.

10. Roggiani M, Stoehr JA, Olmsted SB, Matsuka YV, Pillai S, Ohlendorf DH, Schlievert PM: Toxoids of streptococcal pyrogenic exotoxin $A$ are protective in rabbit models of streptococcal toxic shock syndrome. Infect Immun 2000, 68:5011-5017.

11. McCormick JK, Tripp TJ, Olmsted SB, Matsuka YV, Gahr PJ, Ohlendorf DH, Schlievert PM: Development of streptococcal pyrogenic exotoxin $\mathrm{C}$ vaccine toxoids that are protective in the rabbit model of toxic shock syndrome. J Immunol 2000, $165: 2306-2312$ 